\title{
Effect of sewage-water irrigation on physico-chemical parameters with special reference to heavy metals in agricultural soil of Haridwar city
}

\author{
Chakresh Pathak*, A. K. Chopra, Vinod K umar and Sunil Sharma \\ Department of Zoology and Environmental Science,Gurukula Kangri University, Haridwar -249404 (Uttarakhand), \\ INDIA \\ *Corresponding author. E-mail: chakreshpathak@yahoo.co.in
}

\begin{abstract}
The present study revealed that use of sewage for irrigation of agricultural soil of Haridwar city improved the water holding capacity $(+27.98 \%)$, electrical conductivity $(+196.15 \%)$, sulphate $(+2.34 \%)$, organic carbon $(+30.48 \%)$, total Kjeldhal nitrogen $(+87.5 \%)$, available potassium $(+25.77 \%)$ and available phosphorous $(+59.97 \%)$ and fertility status of the soil in comparison to natural water irrigated soil. Further sewage irrigation also resulted in a significant build-up of total $\mathrm{Pb}(+98.95 \%), \mathrm{Ni}(+128.29 \%), \mathrm{Cu}(+253.17 \%)$, Fe $(+39.74 \%), \mathrm{Cd}(+30.92 \%), \mathrm{Zn}$ $(+696.03 \%)$ and $\mathrm{Cr}(+13.15 \%)$ than the natural water irrigated soil. The mean concentrations of these metals were below the permissible limits of Indian standards. The enrichment factor (Ef) for $\mathrm{Cu}$ (9.62) was maximum and minimum for $\mathrm{Cr}$ (1.13). The Ef for different metals was in the order of $\mathrm{Cu}>\mathrm{Zn}>\mathrm{Ni}>\mathrm{Pb}>\mathrm{Cd}>\mathrm{Cr}>\mathrm{Fe}$. Pollution index (Pi) value of the sewage water irrigated soil ranged from 0.505 to 0.901 which indicated that the soil was not yet polluted.
\end{abstract}

Keywords: Soil, Heavy metal, Enrichment factor, Pollution index

\section{INTRODUCTION}

Soil pollution by heavy metals is a worldwide problem arising mainly from anthropogenic sources such as mining, industry and agriculture. The use of treated sewage effluents for agricultural irrigation has been a popular practice in agriculture (Feigin et al., 1991).Treated sewage sludge is an ultimate product of municipal wastewater treatment. It may be deposited in landfills, in the sea (ocean disposal), under the ground, or (to a certain extent) in the air as a consequence of incineration. In addition, Total suspended solids can be recycled in various ways, including its use as fertilizer, as a soil conditioner in farmland, in forests and in home gardens (Delibacak et al., 2009). The long-term land application of suspended solids and compost from waste materials may be limited by accumulation of harmful heavy metals and pathogens in soil.

Contamination by potentially toxic elements in the natural environment is one of the major problems for human health and environment quality (Chen et al., 2000; Sakan et al., 2010) because these elements are indestructible and most of them have toxic effects on living organisms when they exceed a certain concentration (Ghrefat and Yusuf, 2006; Sakan et al., 2010). Soil contamination is the result of human activity, including the entry of industrial wastes into soil through atmospheric deposition or application of agrochemicals and dumping of domestic waste to the land. These contaminants reduce the soil quality for agricultural production. Soils also play an important role for the global flux for pesticides in the environment (Sanghi and Sasi, 2001; Ansari and Malik, 2010). They are very important in the fate and distribution of persistent toxic substances in the environment since they have a huge retention capacity and they may work as re-emission sources for the atmosphere (Harner et al. 2001; Barra et al., 2005; Ansari and Malik, 2010).

Heavy metals are dangerous because they tend to bioaccumulate in living things any time they are taken up and stored faster than they are broken down (metabolized) or excreted (Mashi and Alhassan, 2007). Heavy metals occupy a special position among environment pollutants as they are not biodegradable, accumulate in plants and animals, and enter the biochemical cycles where they are transformed into various organometallic compounds (Cuny et al., 2004; Al-Khateeb and Leilah, 2005).

The soil is a long-term sink for the group of potentially toxic elements often referred to as heavy metals like zinc, copper, nickel, lead, chromium, and cadmium. While these elements display a range of properties in agricultural soil, including differences in mobility and bioavailability, leaching losses and plant uptake are usually relatively small compared to the total quantities entering the soil from different diffuse and agricultural sources (Ansari and Malik, 2010). Metals such as lead, mercury, cadmium and copper are cumulative poisons. These metals cause 
environmental hazards and are reported to be exceptionally toxic (Yargholi and Azimi, 2008; Bigdeli and Seilsepour, 2008). Metal contamination soils may be widespread in urban areas due to past industrial activity and the use of fossil fuels (Bigdeli and Seilsepour, 2008). The present study was undertaken to observe the effect of sewage-water irrigation on soil quality in terms of physico-chemical parameters and to evaluate the sensitivity of different metals.

\section{MATERIALS AND METHODS}

Study area: The study was conducted in winter season for a period of three months between February to April, 2009. Two sampling sites were selected- i) Experimental site - Sewage water irrigated agricultural soil, near sewage treatment plant, Jagjeetpur, Haridwar and Control sitetube well-water irrigated agricultural soil near at Gurukula Kangri University, Haridwar.

Soil analysis: The soil was analyzed for the physicochemical parameters following standard methods Bulk density (BD) by Carter,1993, Water holding capacity (WHC) by Saxena, 1990, pH and Electrical conductivity (EC) by taking the soil: water ratio of $1: 2$ using glass electrode $\mathrm{pH}$ meter and Electrical conductivity meter respectively by Chaturvedi and Sankar, 2006; Organic carbon (OC) by Walkley and Black, 1934 ; Sulphate $\left(\mathrm{SO}_{4}^{-}\right)$ by Chaturvedi and Sankar 2006, Total nitrogen by the Kjeldahl method of Bremner and Mulvaney, 1982, available phosphorous $(\mathrm{P})$ in soil on extraction with sodium bicarbonate by Olsen et al., 1954 and available potassium $(\mathrm{K})$ by Ammonium acetate method of Hanway and Heidel, 1952.

Deter mination of heavy metal content: The soil samples were dried in air at room temperature and sieved through $2 \mathrm{~mm}$ sieve. Samples were digested in di acid as per the method described in AOAC (1990). The digestion was performed with a mixture $\mathrm{HNO}_{3}$ and $\mathrm{HClO}_{4}$ acid. After digestion all samples were filtered through Whatmann No. 42 filter paper and in each case volume was made to $50 \mathrm{ml}$. Heavy metals such as Lead ( $\mathrm{Pb})$, Zinc (Zn), Copper $(\mathrm{Cu})$, Nickel (Ni), Chromium (Cr), Cadmium (Cd) and Iron $(\mathrm{Fe})$ were determined in the digested aliquot by Atomic Absorption Spectrophotometer (AAS) (Make - Perkin Elmer, model analyst 700) using specific lamp of particular metal using appropriate drift blank.

Determination of enr ichment factor (EF) and pollution index $(\mathrm{Pi})$ : The EF for heavy metals in sewage water irrigated soil was calculated as follows using method of Kim and Kim(1999).

$\mathrm{Ef}=\frac{\text { Mean metal concentration of experimental soil }}{\text { Metal concentration of control soil }}$

PI of each sediment and soil sample was computed by the average ratio of element concentrations in a sample to tolerable levels of soils for plant growth suggested by
Klorke (1979).When the Pi values exceed 1.0, the soil is contaminated by anthropogenic inputs and may recommend continuous environmental monitoring of the area.

\section{RESULTS AND DISCUSSION}

The mean values $( \pm$ SD) and percentage $(\%)$ increase and decrease of different physico-chemical parameters viz. $\mathrm{BD}, \mathrm{WHC}, \mathrm{EC}, \mathrm{pH}, \mathrm{SO}_{4}^{--}, \mathrm{OC}, \mathrm{TKN}$, available $\mathrm{K}$, available $\mathrm{P}$ trace elements $(\mathrm{Pb}, \mathrm{Ni}, \mathrm{Cu}, \mathrm{Fe}, \mathrm{Cd}, \mathrm{Zn}$ and $\mathrm{Cr}$ ) in sewage water irrigated and tube well water irrigated soils of Haridwar are shown in Table 1.

Physico-chemical properties of soil: The present study indicated that there was no much variation in percentage of physico-chemical parameter like BD $\left(0.96 \pm 0.05 \mathrm{~g} / \mathrm{cm}^{3}\right.$, $-8.57 \%)$, WHC $(53.33 \pm 5.77 \%,+27.98 \%), \mathrm{pH}(6.97 \pm 0.08$, $4.39 \%), \mathrm{SO}_{4}^{-}(6.99 \pm 0.75 \mathrm{mg} / 100 \mathrm{~g},+2.34 \%), \mathrm{OC}(2.44 \pm 0.28$ $\%,+30.48 \%)$ and available $\mathrm{K}(41.00 \pm 3.46 \mathrm{mg} / 100 \mathrm{gm}$, $+25.77 \%$ ) but on the other hand the notable variation was found in EC $\left(3.85 \pm 1.26 \mathrm{dsm}^{-1},+196.15 \%\right)$, TKN $(0.15 \pm 0.02 \%,+87.5 \%)$ and available $\mathrm{P}(10.67 \pm 1.76 \mathrm{ppm}$, $+59.97 \%)$ in comparison to tube well water irrigated soil. Students't-test was used for significant difference in mean values of the different parameters of the sewage irrigated soil and control soil. It was revealed that the WHC, EC, $\mathrm{SO}_{4}{ }^{-}$and TKN were significantly $(\mathrm{P}<0.05)$ more in sewage water irrigated soil whereas the $\mathrm{BD}, \mathrm{pH}, \mathrm{OC}, \mathrm{P}$ and $\mathrm{K}$ were insignificantly $(\mathrm{P}>0.05)$ higher (Table 1$)$.

Ramulu (2001) stated that the BD of the soil changes with land use and management practices. Renukaprasanna et al. (2002) reported that the sewage water irrigated soils had lower BD and higher porosity, volume of expansion and maximum WHC as compared to unirrigated soil. This may be due to the addition of organic matter through sewage water irrigation. The BD of soil depends greatly on the mineral make up of soil and the degree of compaction (Anu et al., 2010).WHC is related to the number and size distribution of soil pores and consequently increases with soil organic matter level. It is related to soil moisture content, textural class, structure, salt content and organic matter as stated by Vinod and Chopra (2010). During the present study the BD was found to decrease while WHC increased in sewage water irrigated soil in comparison to control soil as also reported by Renukaprasanna et al. (2002) for BD and Masto et al. (2008) for WHC of sewage irrigated soil. The soil $\mathrm{pH}$ is also one of the major factors controlling the availability of heavy metals. Charman and Murphy (1991) reported that the basic $\mathrm{pH}$ of the soil reduces the solubility of all micronutrients (except chlorine, boron and molybdenum), especially those of iron, zinc, copper and manganese. Smith (1994) noted that optimal $\mathrm{pH}$ value for growth of the majority of plants was between 6.5 and 7.0. Masto et al. (2008) suggested that the $\mathrm{pH}$ was not 
Table 1. Physico-chemical properties and the paired two sample t-test for sewage and tube well water irrigated soil.

\begin{tabular}{|c|c|c|c|c|c|c|c|}
\hline Parameters & Study site & Control site & $\begin{array}{c}\text { (\%) Increase/ } \\
\text { decrease }\end{array}$ & $\begin{array}{c}\text { t- } \\
\text { statistics }\end{array}$ & $\begin{array}{c}\text { t- } \\
\text { critical }\end{array}$ & $\begin{array}{l}\text { Tolerable } \\
\text { limits }\end{array}$ & $\begin{array}{l}\text { Limits of } \\
\text { Indian } \\
\text { standards }\end{array}$ \\
\hline $\mathrm{BD}\left(\mathrm{g} / \mathrm{cm}^{3}\right)$ & $0.96 \pm 0.05$ & $1.05 \pm 0.05$ & -8.57 & -3.02 & $1.86^{*}$ & - & - \\
\hline WHC (\%) & $53.33 \pm 5.77$ & $41.67 \pm 7.64$ & +27.98 & 7.00 & 2.92 & - & - \\
\hline $\mathrm{pH}$ & $6.97 \pm 0.08$ & $7.29 \pm 0.03$ & -4.39 & -6.40 & $2.92 *$ & - & - \\
\hline $\mathrm{EC}\left(\mathrm{dsm}^{-1}\right)$ & $3.85 \pm 1.26$ & $1.30 \pm 0.37$ & +196.15 & 5.19 & 2.02 & - & - \\
\hline $\mathrm{SO}^{-4}(\mathrm{mg} / 100 \mathrm{~g})$ & $6.99 \pm 0.75$ & $6.83 \pm 4.40$ & +2.34 & 21.63 & 2.92 & - & - \\
\hline $\mathrm{OC}(\%)$ & $2.44 \pm 0.28$ & $1.87 \pm 0.25$ & +30.48 & 0.05 & $2.92 *$ & - & - \\
\hline $\mathrm{TKN}(\%)$ & $0.15 \pm 0.02$ & $0.08 \pm 0.01$ & +87.5 & 4.78 & 2.92 & - & - \\
\hline $\mathrm{K}(\mathrm{ppm})$ & $41.00 \pm 3.46$ & $32.6 \pm 4.87$ & +25.77 & 1.92 & $2.92 *$ & - & - \\
\hline $\mathrm{P}(\mathrm{mg} / 100 \mathrm{gm})$ & $10.67 \pm 1.76$ & $6.67 \pm 1.89$ & +59.97 & 1.75 & $2.92 *$ & - & - \\
\hline $\mathrm{Pb}(\mathrm{mg} / \mathrm{kg})$ & $\begin{array}{l}83.22 \pm 2.50 \\
(\mathrm{Pi}=0.832)\end{array}$ & $\begin{array}{l}41.83 \pm 2.30 \\
(\mathrm{Pi}=0.418)\end{array}$ & +98.95 & 183.83 & 2.92 & 100 & $250-500$ \\
\hline $\mathrm{Ni}(\mathrm{mg} / \mathrm{kg})$ & $\begin{array}{l}35.27 \pm 2.51 \\
(\mathrm{Pi}=0.588)\end{array}$ & $\begin{array}{l}15.45 \pm 1.47 \\
(\mathrm{Pi}=0.154)\end{array}$ & +128.29 & 9.85 & 2.92 & 60 & $75-150$ \\
\hline $\mathrm{Cu}(\mathrm{mg} / \mathrm{kg})$ & $\begin{array}{l}90.13 \pm 9.41 \\
(\mathrm{Pi}=0.901)\end{array}$ & $\begin{array}{l}25.52 \pm 2.85 \\
(\mathrm{Pi}=0.255)\end{array}$ & +253.17 & 9.97 & 2.92 & 100 & $135-270$ \\
\hline $\mathrm{Fe}(\mathrm{mg} / \mathrm{kg})$ & $\begin{array}{c}487.05 \pm 59.37 \\
(-)\end{array}$ & $\begin{array}{c}348.54 \pm 14.75 \\
(-)\end{array}$ & +39.74 & 3.72 & 2.92 & - & $50000^{\mathrm{a}}$ \\
\hline $\mathrm{Cd}(\mathrm{mg} / \mathrm{kg})$ & $\begin{array}{c}5.42 \pm 1.32 \\
(-)\end{array}$ & $\begin{array}{c}4.14 \pm 1.09 \\
(-)\end{array}$ & +30.92 & 1.84 & $2.92 *$ & - & $3-6$ \\
\hline $\mathrm{Zn}(\mathrm{mg} / \mathrm{kg})$ & $\begin{array}{c}254.65 \pm 32.95 \\
(\mathrm{Pi}=0.849)\end{array}$ & $\begin{array}{l}31.99 \pm 2.84 \\
(\mathrm{Pi}=0.107)\end{array}$ & +696.03 & 10.89 & 2.92 & 300 & $300-600$ \\
\hline $\mathrm{Cr}(\mathrm{mg} / \mathrm{kg})$ & $\begin{array}{l}25.22 \pm 2.38 \\
(\mathrm{Pi}=0.505)\end{array}$ & $\begin{array}{l}22.29 \pm 0.76 \\
(\mathrm{Pi}=0.446)\end{array}$ & +13.15 & 1.69 & $2.92 *$ & 50 & $100^{\mathrm{a}}$ \\
\hline
\end{tabular}

All values are Mean \pm Std. of 5 observations for each parameter, Pi= Pollution index, *Insignificant, Kabata-Pendias and Pendias (1990)

affected due to sewage water irrigation, probably due to the improvement in soil buffering capacity owing to increase in soil clay content. However, in present study the soil $\mathrm{pH}$ changed to the acidic nature in sewage water irrigated soil. It may be due to the acidic nature of sewage water and also low buffering capacity of the soil.

$\mathrm{EC}$ is used for measuring the current capacity that's gives a clear idea of soluble salts present in the soil. Conductivity depends on the dilution of the soil suspension. Charman and Murphy (1991) has concluded that the EC of water and waste water is due to the presence of total dissolved solids. It is an important criterion to determine the suitability of water and waste water for irrigation. Renukaprasanna et al. (2002) reported that the sewage irrigation increased the EC of soil and although less than $4 \mathrm{dsm}^{-1}$ at present and may pose problem on prolonged use particularly on ill-drained soils. According to Saha et al. (2010) irrigation with sewage water resulted in significant increase in EC in the surface soil, though not to the extent that can cause any adverse effect in the rhizosphere environment. During present study the EC was more in sewage irrigated soil. Similar findings have also been reported by Renukaprasanna et al. (2002) for sewage water irrigated soil.

The sources of OC in the cultivated soil included crop residue, animal manure, cover crops, green manure and organic fertilizer etc. Masto et al. (2009) observed that OC ranged from $0.510 \%$ to $0.860 \%$ in long term sewage water irrigated soil. Saha et al. (2010) observed OC 5.10 $\mathrm{g} / \mathrm{kg}$ in soil (depth from 0-15) due to sewage irrigation at Bhopal. Dikinya and Areola (2010) found OC $0.69 \%-2.68$ $\%$ in wastewater irrigated soils of Gaborone City, Botswana. During present study, the OC was more in sewage water irrigated soil as also reported by Saha et al. (2010) and Dikinya and Areola (2010) for secondary treated wastewater irrigated soil .

Nitrogen is the most important fertilizer element. Plant responds quickly to application of nitrogen. Siebe (1998) also observed significant increase in available $\mathrm{P}$ due to long-term wastewater irrigation near Mexico City. Masto et al. (2009) found total $\mathrm{N}$ ranged from $1,869 \mathrm{~kg} \mathrm{ha}^{-1}$ to $2,713 \mathrm{~kg} \mathrm{ha}^{-1}$, av. K ranged from $524 \mathrm{~kg} \mathrm{ha}^{-1}$ to $334 \mathrm{~kg} \mathrm{ha}^{-1}$, av. P ranged from $112.7 \mathrm{~kg} \mathrm{ha}^{-1}$ to $128 \mathrm{~kg} \mathrm{ha}^{-1}$ in sewage water irrigated soil at New Delhi. Saha et al. (2010) observed total N-1017 $\mu \mathrm{g} / \mathrm{g}$, av. K - $283 \mu \mathrm{g} / \mathrm{g}$, av. P- 11.80 $\mu \mathrm{g} / \mathrm{g}$ in soil due to sewage irrigation at Bhopal. Duan et al. (2009) concluded that the increase in available $\mathrm{N}$ content was due to addition of sewage that might have been as a result of increased microbial activity leading to greater mineralization. Mineralization is the process of 
Table 2. Enrichment factor (Ef) of heavy metals in sewage irrigated soil.

\begin{tabular}{cll}
\hline $\mathrm{M}$ etals & $\mathrm{EF}$ & Contamination categories \\
\hline $\mathrm{Pb}$ & 1.99 & Deficiency to mineral enrichment \\
$\mathrm{Ni}$ & 2.28 & Moderate enrichment \\
$\mathrm{Cu}$ & 9.62 & Significant enrichment \\
$\mathrm{Fe}$ & 1.10 & Deficiency to mineral enrichment \\
$\mathrm{Cd}$ & 1.31 & Deficiency to mineral enrichment \\
$\mathrm{Zn}$ & 7.96 & Significant enrichment \\
$\mathrm{Cr}$ & 1.13 & Deficiency to mineral enrichment \\
\hline
\end{tabular}

converting nitrogen from the organic form to the inorganic form by microbial decomposition. Immobilization is the process of converting nitrogen from the inorganic form to organic form by assimilation by plants and soil microorganisms.

Yadav et al. (2002) reported that soil irrigated with sewage water contained higher amount of available phosphorus which plays significant role in plant growth and strengthening the root system. Long-term sewage application has been found to increase available $\mathrm{P}$ and $\mathrm{K}$ contents in soils of different places (Siebe, 1998; Ryan et al., 2006). The present study found that $\mathrm{N}, \mathrm{P}$ and $\mathrm{K}$ was more in sewage water irrigated soil in comparison to tube well water irrigated soil. Similar findings have also been reported by Masto et al. (2009) and Saha et al . (2010) for sewage irrigated soil.

H eavy metals contents in soil: In present study, the results of paired two sample t-test for the metals like $\mathrm{Pb}, \mathrm{Ni}, \mathrm{Cu}$, $\mathrm{Fe}, \mathrm{Cd}, \mathrm{Zn}$ and $\mathrm{Cr}$ (Table 4) revealed that the concentrations of $\mathrm{Pb}, \mathrm{Ni}, \mathrm{Cu}, \mathrm{Fe}$ and $\mathrm{Zn}$ were significantly $(\mathrm{P}<0.05)$ higher in wastewater irrigated soil than that observed in natural water irrigated soil. But the $\mathrm{Cd}$ and $\mathrm{Cr}$ concentrations were insignificantly $(\mathrm{P}>0.05)$ more in treated sewage water irrigated soil. It was also observed that the sewage water irrigation increased the amount of heavy metals such as $\mathrm{Zn}, \mathrm{Pb}, \mathrm{Cu}, \mathrm{Ni}, \mathrm{Cr}$ and $\mathrm{Cd}$ in the soil.

Amusan et al. (2005) found Fe content $925.93 \mu \mathrm{g} / \mathrm{g}$ of soil in Bode - Osi (rural community) and $2527.34 \mu \mathrm{g} / \mathrm{g}$ of soil in OAU, Ife (municipal) while Cd content $17.00 \mu \mathrm{g} / \mathrm{g}$ of soil in Bode - Osi (rural community) and $47.06 \mu \mathrm{g} / \mathrm{g}$ of soils in OAU, Ife (municipal). Amiri et al. (2008) found $\mathrm{Pb}$ $(78.4 \pm 2.01 \mathrm{mg} / \mathrm{kg}), \mathrm{Ni}(46.00 \pm 1.52 \mathrm{mg} / \mathrm{kg})$ at depth $0-15$ and $(53.04 \pm 1.03 \mathrm{mg} / \mathrm{kg}),(36.41 \pm 0.57 \mathrm{mg} / \mathrm{kg})$ at a depth $15-30 \mathrm{~cm}$ in soils irrigated with urban wastewater, in the urban fringe area of Tehran city. Masto et al. (2008) found DTPA- Fe (12.3- $\left.37.7 \mathrm{mg} \mathrm{kg}^{-1}\right)$, DTPA- Cd (0.03$0.091 \mathrm{mg} \mathrm{kg}^{-1}$ ) of long term sewage irrigated soils in New Delhi. Mishra and Tirpathi (2008) observed that the concentration of $\mathrm{Pb}(123.50 \pm 18.40 \mathrm{mg} / \mathrm{kg}), \mathrm{Zn}$ $(122.30 \pm 17.90 \mathrm{mg} / \mathrm{kg}), \mathrm{Cu}(77.8 \pm 15.2 \mathrm{mg} / \mathrm{kg}), \mathrm{Cd}(3.4 \pm 1.1$ $\mathrm{mg} / \mathrm{kg})$ and $\mathrm{Cr}(56.3 \pm 8.9 \mathrm{mg} / \mathrm{kg})$ was quite higher in the soil irrigated with treated waste water at Varanasi. Jagtap et al. (2010) found $\mathrm{Pb}(84.77 \mathrm{mg} / \mathrm{kg}$ to $134.19 \mathrm{mg} / \mathrm{kg})$, Ni $(48.88 \mathrm{mg} / \mathrm{kg}$ to $80.76 \mathrm{mg} / \mathrm{kg}), \mathrm{Cu}(155.11 \mathrm{mg} / \mathrm{kg}$ to 211.08 $\mathrm{mg} / \mathrm{kg}), \mathrm{Zn}(165.73 \mathrm{mg} / \mathrm{kg}$ to $231.27 \mathrm{mg} / \mathrm{kg}), \mathrm{Cd}(65.26 \mathrm{mg} /$ $\mathrm{kg}$ to $115.27 \mathrm{mg} / \mathrm{kg}$ ), Cr (47.97 to $97.75 \mathrm{mg} / \mathrm{kg}$ ) in soils irrigated with urban wastewaters Solapur city, Maharashtra (India). In present study, the concentration of heavy metals in sewage water irrigated soil was found $\mathrm{Pb}(83.22 \pm 2.50 \mathrm{mg} / \mathrm{kg}, 98.95 \%), \mathrm{Ni}(35.27 \pm 2.51 \mathrm{mg} / \mathrm{kg}$, $128.29 \%), \mathrm{Cu}(90.13 \pm 9.41 \mathrm{mg} / \mathrm{kg}, 253.17 \%), \mathrm{Zn}$ $(254.65 \pm 32.95 \mathrm{mg} / \mathrm{kg},+696.03 \%), \mathrm{Fe}(487.05 \pm 59.37 \mathrm{mg} / \mathrm{kg}$, $+39.74 \%), \mathrm{Cd}(5.42 \pm 1.32 \mathrm{mg} / \mathrm{kg},+30.92 \%)$ and $\mathrm{Cr}$ $(25.22 \pm 2.38 \mathrm{mg} / \mathrm{kg},+13.15 \%)$ in comparison to the tube well water irrigated soil. However, the remarkable increase of $\mathrm{Pb}, \mathrm{Cu}, \mathrm{Ni}$, and $\mathrm{Zn}$ was observed in sewage irrigated soil. There was no much variation in $\mathrm{Fe}, \mathrm{Cd}$ and $\mathrm{Cr}$ in this type of soil. The present data also revealed that the level of heavy metals in soil was lower than those reported in such type of sewage irrigated soil at New Delhi (Masto et al., 2008), but higher than that observed for the soil at Varanasi (Mishra and Tirpathi, 2008) and Solapur city (Jagtap et al., 2010).

Enrichment factor and pollution index: The Ef of $\mathrm{Pb}, \mathrm{Ni}$, $\mathrm{Cu}, \mathrm{Fe}, \mathrm{Cd}, \mathrm{Zn}$ and $\mathrm{Cr}$ in the sewage water irrigated soil are presented in Table 4. The Ef was found in the order of : $\mathrm{Cu}>\mathrm{Zn}>\mathrm{Ni}>\mathrm{Pb}>\mathrm{Cd}>\mathrm{Cr}>\mathrm{Fe}$. The Ef for $\mathrm{Cu}(9.62)$ was maximum and minimum for $\mathrm{Cr}$ (1.13). According to the contamination categories established by Sutherland (2000), the studied soil $\mathrm{Cu}(9.62)$ and $\mathrm{Zn}$ (7.96) was found to be in significant enrichment categories, $\mathrm{Ni}$ (2.28) was moderate enrichment categories, $\mathrm{Pb}$ (1.99), $\mathrm{Fe}$ (1.10), $\mathrm{Cd}$ (1.31) and $\mathrm{Cr}$ (1.13) were found in deficient enrichment categories (Table 5). The Pi of the soils and sediments were higher than 1.0 and that was due to anthropogenic and industrial activities and not due to geochemical aspects of the environment. In the present study, PI value of the analyzed samples ranged from 0.505 to 0.901 at sewage water irrigated soil whereas at control site it ranged from 0.107 to 0.446 which confirmed that both type of soil are in unpolluted condition.

\section{Conclusion}

The present study concluded that the parameters like WHC and EC were higher in sewage water irrigated soil of Haridwar city. The sewage water improved the organic carbon $(+30.48 \%)$ and fertility status in terms of TKN $(+87.5 \%), \mathrm{P}(+59.97 \%)$ and $\mathrm{K}(+25.77 \%)$ of the soil which are the essential nutrients (NPK) for the growth of plants. It was also determined that the sewage irrigation extremely increased the amount of heavy metals such as $\mathrm{Zn}(+696.03 \%), \mathrm{Cu}(+253.17 \%), \mathrm{Ni}(+128.29 \%)$ and $\mathrm{Pb}$ $(+98.95 \%)$ in the soil. The concentration of these metals in the soil was below the permissible limits of Indian standards. However, if the sewage water irrigation is used for a prolonged time, the metal enrichment may exceed 
the permissible limits in soil which can be hazardous for the fertility of the soil. Hence monitoring is needed from time to time where the soil is being irrigated with sewage.

\section{ACKNOW LEDGEMENTS}

The University Grants Commission, New Delhi is acknowledged for providing the financial support in the form of UGC research fellowship (F.7-70/2007 BSR) to Chakresh Pathak.

\section{REFERENCES}

Al-Khateeb, S. A. and Leilah, A. A. (2005). Heavy metals accumulation in the natural vegetation of Eastern Province of Saudi Arabia. J ournal of Biological Sciences, 5(6): 707712.

Amiri, S. S., Maralian, H. and Aghabarati, A. (2008). Heavy metal accumulation in M elilotus officinalis under crown Olea europaea L forest irrigated with wastewater. A frican J ournal of Biotechnology, 7 (21): 3912-3916.

Amusan, A. A., Ige, D.V. and R. Olawale (2005). Characteristics of Soils and Crops uptake of metals in municipal waste dump sites in Nigeria. J. Hum. Ecol., 17(3): 167-171.

Ansari, Mohd Ikram and Malik, Abdul (2010). Seasonal variation of different microorganisms with nickel and cadmium in the industrial wastewater and agricultural soils. Environ M onit Assess., 167:151-163.

Anu, Upadhyaya, S.K. and Bajpai Avinash(2010). Seasonal Analysis of Soil Sediment of Shahpura Lake of Bhopal (M.P.). International Journal of Environmental Science and Development, 1 (4): 333 - 335.

AOAC (1990). Official methods of Analyses. Method No. 975.03 metal in plants, AAS method. Association of Official Analytical Chemists, Inc. USA. 15 $5^{\text {th }}$ Edition. pp 42.

Barra, R., Popp, P., Quiroz, R., Bauer, C., Cid, H., and von Tumpling, W. (2005). Persistent toxic substances in soils and waters along an altitudinal gradient in the Laja River Basin, Central Southern Chile. Chemosphere, 58(7): 905915.

Bremner, J. M. and Mulvaney, C. S. (1982). Nitrogen-total. In: Page AL et al (eds) Methods of soil analysis. Part 2 Chemical and microbiological properties. American Society of Agronomy, Madison, pp 595-624.

Bigdeli, M. and Seilsepour, M. (2008). Investigation of Metals Accumulation in Some Vegetables Irrigated with Waste Water in Shahre Rey-Iran and Toxicological Implications. American-Eurasian J . Agric. \& Environ. Sci., 4 (1): 86-92.

Carter, M.R. (1993). Soil sampling and method of analysis, Lewis Publishers, Boca Raton, FL.

Chen, Z. S., Lee, G. J. and Liu, J. C. (2000). The effects of chemical remediation treatments on the extractability and speciation of cadmium and lead in contaminated soils. Chemosphere, 41: 235-242.

Chaturvedi, R.K. and Sankar, K. (2006). Laboratory manual for the physico-chemical analysis of soil, water and plant. Wildlife Institute of India, Dehradun. Pp 97.

Charman, P.E.V. and Murphy, B.W (2000). Soils. Their Properties and Management. In a Soil Conservation Handbook for New South Wales. Sydney University Press.
Sydney. pp 464.

Cuny, D., Denayer, F. O., Foucault, R., Schumacker, P. and Haluwayn, C. V. (2004). Patterns of metal soil contamination and changes in terrestrial cryptogamic communities. Environmental Pollution, 129, 289-297

Delibacak, S., Okur, B. and Ongun, A. R. (2009). Effects of treated sewage sludge levels on temporal variations of some soil properties of a typic xerofluvent soil in menemen plain, Western Anatolia, Turkey. Envir on M onit Assess., 148:8595

Dikinya, O. and Areola, O. (2010). Comparative analysis of heavy metal concentration in secondary treated wastewater irrigated soils cultivated by different crops. Int. J . Environ. Sci. Tech., 7 (2), 337-346

Duan, R., Fedler, C.B. and Sheppard, C. D. (2009b). Nitrogen leaching losses from a wastewater land application system. Water Environment Research, accepted, doi:10.2175/ 106143009X12487095236397

Feign, A., Ravina, I. and Shalhevet, J. (1991). Irrigation with treated sewage effluent: management for environmental protection. Springer, Berlin.

Ghrefat, H. and Yusuf, N. (2006). Assessing Mn, Fe, Cu, Zn and $\mathrm{Cd}$ pollution in bottom sediments of Wadi Al- Arab Dam, Jordan. Chemosphere, 65 : 2114 - 2121.

Harner, T., Bidleman, T. F., Jantunen, L. M. M. and Mackay, D. (2001). Soil air exchange model of persistent pesticides in the United States cotton belt. Environmental Toxicology and Chemistry, 20 (7):1612-1621.

Hanway, J.J. and H. Heidq (1952). Soil analysis methods as used in Iowa state college soil testing laboratory. Iowa Agri., 57:1-31.

Jagtap, M. N., Kulkarni, M. V. and Puranik, P. R. (2010). Flux of heavy metals in soils irrigated with urban wastewaters. American Eurasian J. Agric. \& Environ. Sci., 8 (5): 487493.

Kabata-Pendias, A. and Pendias, H. (1992). Trace Elements in Soils and Plants, second ed. CRC Press, Boca Raton, FL, USA.

Kim, K. H., and Kim, S. H. (1999). Heavy metal pollution of agricultural soils in central regions of Korea. Water, Air and Soil Pollution, 111: 109-122.

Kloke, A. (1979). Content of arsenic, cadmium, chromium, flourine, lead, mercury and nickel in plants grow on contaminated soil, Paper presented at United Nations ECE, Symposium.

Masto, R .E., Chhonkar P. K. , Singh, D. and Patra, A. K. (2008). Changes in soil quality indicators under long-term sewage irrigation in a sub-tropical environment. Environ Geol., DOI 10.1007/s00254-008-1223-2.

Mishra, Archana and Tripathi, Brahma Dutt (2007). Heavy metal contamination of soil, and bioaccumulation in vegetables irrigated with treated waste water in the tropical city of Varanasi, India. Toxicological \& Environmental Chemistry, 1-10. DOI: 10.1080/02772240701740197.

Mashi, S. A. and Alhassan, M. M. (2007). Effects of wastewater discharge on heavy metals pollution in fadama soils in Kano city, Nigeria. Biomedical and Environmental Sciences, 20: 70-77.

Olsen, S.R., C.V. Cole, F.S. Watanabe and L.A. Qean (1954). Estimation of available phosphorus in soils by extraction 
with sodium bicarbonate. Cire USQep. Agri. Q 39.

Ramulu Sree, U.S. DR. (2001). Reuse of municipal sewage and sludge in agriculture. Scientific publishers (India), Jodhpur: 86. Renukaprasanna, M., Channal, H. T. and Sarangamath, P. A. (2002). Charactrisation of city sewage and its impact on soils and water bodies. $17^{\text {th }}$ WCSS Thailand. Poster presentation Paper No. 70, Symposium no 24.

Ryan, John, Masri, Samir and Manzoor Qadir (2006). Nutrient monitoring of sewage water irrigation: Impacts for soil quality and crop nutrition. Communications in Soil Science and Plant Analysis, 37: 2513-2521.

Sakan, S., Dordevic, M., Dragana S. and Manojlovic, D. D. (2010). Trace elements as tracers of environmental pollution in the canal sediments (alluvial formation of the Danube River, Serbia). Environ M onit Assess., 167:219-233.

Sanghi, R. and Sasi, K. S. (2001). Pesticides and heavy metals in agricultural soils of Kanpur, India. Bulletin of Environmental Contamination and Toxicology, 67: 446 - 454.

Saha, J. K., Panwar, N., Srivastava, A., Biswas, A. K., Kundu, S. and Subba Rao, A. (2010) Chemical, biochemical, and biological impact of untreated domestic sewage water use on Vertisol and its consequences on wheat (Triticum aestivum) productivity. Environ Monit Assess., 161:403412, DOI 10.1007/s10661-009-0756-5.

Saxena, M. M. (1990). Environmental analysis water, soil and air. Agro botanical publishers. pp. 125-126.
Siebe, .C (1998). Nutrient inputs to soils and their uptake by alfalfa through long-term irrigation with untreated sewage effluent in Mexico. Soil U se M anage.,13:1-5.

Smith, S. R. (1994). Effect of soil $\mathrm{pH}$ on availability to crops of metals in sewage sludge-created soils. I. Nickel, copper and zinc uptake and toxicity to ryegrass. Environmental Pollution, 85(3): 321-327.

Sutherland, R. A. (2000). Bed sediment-associated trace metals in an urban stream, Oahu, Hawaii. Environmental G eology, 39:611- 627

Vinod Kumar and Chopra, A. K. (2010). Influence of sugar mill effluent on physico-chemical characteristics of soil at Haridwar (Uttarakhand), India. J . Appl. \& N at. Sci., 2 (2): 269-279.

Walkley, A. and Black, I.A.(1934) An examination of the Degtjareff method for determining soil organic matter and a proposed modification of the chromic acid titration method. Soil Sci. 37:29-38.

Yargholi, B. and Azimi, A. A. (2008). Investigation of Cadmium absorbtion and accumulation in different parts of some vegetables.American Eurasian J. Agric and Environ. Sci., 3(3): 357-364.

Yadav, R.K., Goyal, B., Sharma R.K., Dubey S.K. and Minhas, P.S. (2002). Post irrigation impact of domestic sewage effluent on composition of soils , crops and ground waterA Case study. Environl. Int., 28:481- 486. 